\title{
Improving Students' Vocabulary Mastery through TPR Storytelling
}

\author{
Rusiana \\ Universitas Muria Kudus, Indonesia \\ e-mail:rusiana@umk.ac.id \\ Nuraeningsih \\ Universitas Muria Kudus, Indonesia \\ e-mail:nuraeningsih@umk.ac.id
}

\begin{abstract}
:
Teaching English for primary school students highly emphasizes on vocabulary. It is understandable since they are at the first stage of learning the language. Unfortunately, in many teaching practices, vocabulary is taught in an isolated way without the presence of meaningful context. Vocabularies are often given in the form of long list to be memorized. Actually, the aim of learning vocabulary is to equip the students to be ready to use the language (i.e. speaking). Therefore, here, Total Physical Response Storytelling (TPRS) is to meet with the students' need. TPR Storytelling is one of foreign language teaching methods proposed by Blaine Ray of Bakersfield, California. Using TPRS, teachers told two stories, Crocodile Tears and The Very Hungry Caterpillar and students acted those stories out. The research was conducted to know the influence of TPRS on the student's vocabulary mastery. It elaborates what works and what does not work in implementing TPRS to teach vocabulary. To achieve the purpose of this research, a Classroom Action Research consisting of two cycles was conducted. The subjects of the research were Second Graders of SD in Kudus, Centra Java, Indonesia, with the number of 20 students. Three instruments were used to collect the data, i.e.: test, observation, \& questionnaire. The result of the research shows that the use of TPRS can improve the students' vocabulary mastery. The students' responses on the use of TPRS are also positive. Therefore, teachers are expected to make use of other stories by considering vocabularies that meet with the syllabus and the students' need with the support from the institution.
\end{abstract}

Keywords: Vocabulary Mastery, TPR Storytelling 


\section{Introduction}

At present English has become a great demand worldwide. In ASEAN, the issue of Asean Economic Community has also greatly influence the urge of acquiring English. Indonesia as one of the member nations surely need to take this into account. English that has been considered as a local content in primary schools in Indonesia is still questionable, though. While many elementary schools have been working hard to provide English for the students, the result of the teaching, on the contrary, does not indicate a satisfying performance. This can be a dilemma for teachers and students; many English teachers may get frustrated and students will get less of exposure of English. This seems unfair for the students since they are going to learn English in Junior High School. More importantly, English would be a requirement in many fields. They will probably find it hard to deal with English if they are not introduced with English in primary schools. Lamendella inYuvaraj (2009) claimed that young learners are at an advantage as the brain is more adaptable before puberty, and that acquisition of language is possible without selfconsciousness at an early stage. In line with the previous experts, Sommer (2011) states that one of the main advantages of starting early is that children become accustomed to the intonation and sounds of the new language.

Actually, introducing English to young learners is a challenge for teachers. They will try to find what and how to teach English appropriately in accordance to the students' age. Young learners do not know the importance of studying English. Therefore, the use of any methods and techniques of teaching English should be able to encourage them to study English. In fact, many teaching practices in Primary School seem not seriously designed in order that English is acceptable and understandable. Most of the teachers even use a particular student worksheet (LKS) published by a particular publisher. In fact, the teaching design of English to young learners has to be interesting and motivating. When the children are highly motivated, they will learn maximally. In line with that, they will have a good achievement in English and be able to use English to communicate. Then, vocabulary is the first important thing to be taught that enable one to speak. Teaching vocabularies for Primary School students has to go on the right track. It should be taught in a meaningful context rather than in an isolated way, unless, vocabularies cannot be used in the context. Long list of vocabularies will be useless because the students do not have the prior knowledge of how to put them in the language. Unfortunately, teaching English (i.e vocabulary) in primary schools in Kudus seems to go on the same way. The vocabulary mastery of the students are recognized as unsatisfied since they tend to memorize words only, for example: monyet is monkey, jerapah is giraffe, singa is lion. Surprisingly, that kind of learning strategy does not only take place in Indonesia. Sinhaneti (2012) states that most Asian countries are still utilizing the traditional learning style in which rote learning strategy has been used especially in vocabulary learning because rote learning strategies are most often used as an essential part in vocabulary learning for the Asian EFL learners according to many researches. 
Yet rote learning is criticized as old fashioned and far from being contextual. Regarding to vocabulary acquisition, instead of knowing the meaning of particular words in a loose context, understanding vocabularies in a meaningful context is more important. Dealing with vocabulary, the curriculum of English in elementary schools mainly focuses on responding to new vocabularies or sentences orally with emphasis on vocabulary. In addition, it also addresses to the ability of responding to simple instructions by acting them out. The importance of vocabulary building to improve one's language skills has been emphasized by many researchers (Nunan, 1991; Huckin, 1995; Jabar \& Ali, 2016; Sarani \& Shirzaei, 2016; Munir, 2016).

In conjunction with the aforementioned illustration, TPR Storytelling is proposed as a way to teach and to improve the students' vocabulary mastery. It is expected that the students will be highly motivated by listening and acting out the story and subconsciously influence their vocabulary mastery. This is in line with the research that has been done by Todd McKay on TPR Storytelling. The research is designed as experimental research and the result shows that the TPRS students had significantly higher comprehension compared with the ALM students. The TPRS students had a mean of 7.6 and a standard deviation of 1.83 compared with the ALM students who had a mean of 5.83 and a standard deviation of 1.88 .

TPR storytelling is a method of teaching young learners by telling stories through gestures, image pictures, drawings, etc as a means of providing comprehensible input. It is used ideally to develop a comprehension base and to inspire confidence and motivation in students. Fortunately, kids love stories very much. They even enjoy in listening the same story many times.

Learning English as foreign language for young learners seems to be complex because of some reasons. The most common one is that children are still learning and have not mastered their first language. Consequently, learning English will be difficult because they have to recognize things in different language. Moreover, if they do not really understand about the meaning and the aim of using English, it will be "strange" and "scary" for them. It becomes a challenge to the teachers to be more creative in using various methods and approaches in teaching them.

Therefore, English as a Foreign Language (EFL) for young learners should be introduced in an interesting method. It should be related to their need and interest. In fact, kids love story very much. Moreover, they like moving and learning by doing. Those two interests are covered by TPR storytelling. This method provides the students to have less stress classroom situation that allows them to be involved in the story by imitating what the teacher says and performing the story then. By doing so, the input will be maximum as they learn by doing. This meaningful context enables them to learn English easily. Further, the learning atmosphere will be enjoyable and relaxing in which it will subconsciously encourage them to learn English as a Foreign Language (EFL). This research is to find out how TPR Storytelling can influence the vocabulary mastery of the second graders of an elementary school in Kudus, Indonesia. 


\section{Literature Review}

\subsection{English Young Learners}

Young learners may cover pre-school learners, primary school learners and secondary school or teenage learners. Suhartatik (2008) classifies young learners into the following categories: Children about 4 to 12 years old, Young Group (4-8 years old) and older group (9-12 years old). She further mentions some characteristics of young learners: (1) moody, (2) having short attention and concentration span, (3) having great motivation to do things they like, (4) curious of nearly everything, (5) fond of spoken language and real object, and (6) enjoy physical activities.

The above characteristic will accordingly require special treatment when teaching English to young learners. storytelling with suitable topic of their interests might help the success of their learning. Read (2003) in line with Suhartatik (2008), also proposes some of the optimal conditions for helping young learners to learn, among others are: learning is natural, learning is contextualised and part of a real event, learning is interesting and enjoyable. Similarly Cameron in Sommer (2001) argues that "...young learners develop better pronunciation and listening skills when they begin at an earlier age".

From the perspective of teacher, Cameron (2003) argues that there are number of challenges of teaching English to young learners. It may not bring automatic improvements to proficiency levels, unless teacher education and secondary language teaching both adapt to meet the challenges of the new situation. According to Cameron, amongst other knowledge and skills, teachers of young learners have to be aware of how children think and learn, have skills and knowledge in spoken English to conduct whole lessons orally, and have an ability to identify children's interests and use them for language teaching.

Every child has a potential of learning and learns differently. They surely have their own characteristics; they have different learning styles, needs, preferences, and so forth. It will influence the way they learn, including learning English as a new language. According to constructivism theory, treating children as the subject of learning (students-centered learning) is a good idea since they are active learners. This theory emphasizes that children have their own ability to construct meaning based on what they have learned and known from their environment. In addition, the use of "scaffolding" is also suggested by Psychologists Wood, Bruner, and Ross in Yuvaraj (2009). It will help the students to explore the nature of the support system provided by a teacher or more knowledgeable peers to children learning how to carry out a task they could not perform alone.

\subsection{Total Physical Response Storytelling (TPRS)}

Total Physical Response Storytelling is combination of TPR and storytelling. The originator of Total Physical Response, Asher (2001) claims that TPR is a powerful right-brain tool at all levels of second language instruction while storytelling has long been used as a technique in language teaching. 
Asher (2001) argues that TPR is based on the premise that the human brain has a biological program for acquiring any natural language on earth. The process is visible when we observe how infants internalize their first language. Between the parents and the infant conversation actually takes place in its unique way. When a mother says, "Look at daddy" in repetition, the infant may turns his face in the direction of the voice and daddy exclaims, "She's looking at me" also in repetition. Asher calls this "a language-body conversation" since the parents speak and the infant answers with a physical response such as looking, smiling, laughing, turning, walking, reaching, grasping, holding, sitting, running, and so forth. To be able to produce more intelligible words, a child internalizes the pattern and sounds of the target language beforehandly. A child will be able to speak after decoding sufficient target language gradually (Toaza, 2010).

Storytelling has been known for centuries; It can develop children's imagination and fantasy. People recognize telling stories is able to promote reality in the classroom and the act of imagining and fantasizing provides powerful stimulus for real language use. According to Scott and Lisbeth (1990:30) children do love stories. Therefore, teachers of young learners should utilize stories as the resource in teaching English. Similarly, Wright (1997) and Garvie (1990) argue that stories will be useful either to the students' development in the class or to their language development. In story books, we can find may pictures since generally children do not only love stories but also love pictures. According to Arizpe and Styles (2003: 64) insist that most of children think that pictures are more interesting than words. To their view, books with pictures are good and books with words are boring.

Both of TPR and storytelling are interrelated each other. The story is delivered by utilizing Total Physical Response (TPR). Telling a story with hand gestures (to help students retrieve words in the story) may work if the gestures have an integral connection to the meaning of a vocabulary item. In addition, the teachers have to maximize the use of gestures, facial expression, media, and any other resorts that are necessary (Slattery and Willis, 2001). TPR facilitates students to learn grammatical structure in more advanced structures. Even though storytelling without TPR is possible, but then, using TPR is better since it is helpful for getting students ready to understand a story when they hear it for the first time.

Headstrom (2012) proposes three steps of using TPRS as follows:

Step 1 : Establish Meaning - decide three target structures and provide meaning with written translation and TPR gestures for a few minutes. Have the students understand with the gestures. With interesting commands and comprehension checks, the target structures will stay in their short term memory. Further, students need to be exposed with personalized questions within hours even days in order that the target structures stay in their long term memory.

Step 2 : Tell a Class Story- the purpose of the story is to establish comprehensibe input. Therefore, the the story needs to be short, simple, interesting, contextual, and repetitive. It is presented in a slow pace with steady comprehension checks and ideas from the students. 
Step 3 : Read-Reading is based on the material in the two prior steps that reinforces the content in a different format. More vocabulary and more grammar forms that the students can learn in this step.

Similarly, Davidheiser (2002) followed a traditional TPRS by: 1) beginning with vocabulary gestures that would be mimicked by the students.; 2) having his students write out the commands for homework; 3) asking yes/no questions and factual questions to begin creating a plot to their class story using the vocabulary learned; 4) getting the students write the story in their own words; 5) having the students complete a series of drawings, allowing for creativity by applying what they have learned to new stories and filling in the details. This helps to prevent students from using block memorization as their main learning tool. He differs from the traditional TPR and TPRS approaches by reviewing content grammar. The research revealed the benefits of teaching year one German students with speech and gestures and using constant repetition.

\section{Research Methodoogy}

This research was held in a private elementary school in Kudus, Central Java, Indonesia. There were two classes for each grade and the subject of this research was the second grade students with the number 20 students. As an islamic institution, the school has a mission to educate young learners as what Kuran and Hadist said since early time, so most students tent to respect their teacher and become obedient students. They were active students and seemed have good attitude in learning as the teacher said.

The design of the research was action research. Mills (2004) said that conducting a classroom action research involves four steps in each cycle: planning, acting, observing and reflecting. In this research there were two cycles employed. In the first cycle, the story was Crocodile Tears, and the second cycle the story was The Very Hungry Caterpillar. To obtain the data, the instruments of the present research were observation sheet, test, questionnaire and teacher's journal which is also used to obtain data of teacher's reflection of teaching and learning process she carried out.

In deciding the termintation of the cycles, two criteria were set, i.e.: from the process of teaching learning and the product or the increase of the students' achievement. The detailed explanation can be seen in table 1 .

Table 1. The criteria of success of learning cycles

\begin{tabular}{lcc}
\hline \multicolumn{1}{c}{ Criteria of success } & Source & $\begin{array}{c}\text { Technique of } \\
\text { collecting data }\end{array}$ \\
\hline $\begin{array}{l}\text { Process: students were motivated and } \\
\text { they were actively involved in the }\end{array}$ & Students & $\begin{array}{c}\text { Observation, } \\
\text { questionnaire }\end{array}$ \\
$\begin{array}{l}\text { action } \\
\text { Product }\end{array}$ & $\begin{array}{c}\text { Scores of } \\
\text { The 75\% of students achieved KKM }\end{array}$ & test \\
\hline
\end{tabular}




\section{Findings}

According to the teacher, the students' achievement in English is average. There are about $87 \%$ of the students are highly motivated students. Some students have low capability. On the other hand, the students' attitude and response in English class is good. They are mostly nice boys and girls since they are taught based on character building. Therefore, they tend to be obedient students. Dealing with the teaching and learning process in English class, the teacher admitted that she usually taught the students with conventional method. She rarely used cards or any other media to teach English. She made use of LKS (a worksheet published by a particular publisher that is used by most schools in Kudus). Therefore, this research focuses on the use of stories as the alternative in teaching English especially vocabulary.

With the prior situation as described above, some findings will be discussed in the following. The findings gained from the observation, teacher's journal, questionnaire, and assessment in the last cycle.

\subsection{Teaching Vocabulary Using TPRS}

Before conducting the research, the researchers trained the teacher how to employ story in teaching vocabulary. Before, the media (song, flash cards, and the big book) had been prepared. The teacher was trained how to start the class with song, how to elicit vocabularies stated in the big book by using flash cards, how to use the big book, and how to create activity after reading the story. The stories employed in this research were Crocodile Tears and The Very Hungry Caterpillar.

In this cycle 1, the material was Crocodile Tears. The observation was conducted by the teacher herself and two passive observers in each meeting. They observed the teaching learning process when TPRS was being applied including the teachers' strategy in employing TPRS and students' activeness, behavior, and response during the class. Based on the observation, it seemed that the teacher had followed the steps of teaching as what have been trained. It could be seen that the students were so enthusiastic and interested in listening to the story. The story was Crocodile Tears. The teacher opened the lesson by singing parts of body " head, shoulder, knees, and toes, knees and toes, ...". Then the teacher had the students sing along while touching their parts of body.

In introducing the story, the teacher showed a crocodile realia (a crocodile doll) and its parts of body by using flash cards. The students were so happy to have such kind of media since they had never been taught by using any media. While showing the cards, the teacher elicited answers from the students about the name of each part of body of crocodiles and told them about aches, head: I've got a headache, tummy: I've got a tummyache, Ear: I've got an earache, tooth: I've got a toothache by acting them out. Other flash cards correspond to the vocabularies in the text were also introduced. The students were enthusiastic to have the realia and the cards. When the teacher was telling the story accompanied by action, the students were so exciting. They tentatively listened and looked at the big book. 
After reading the story, the teacher had students repeat the story. Then the teacher alternated couples of students to act out the story chunk by chunk.

Student A: what's the matter?

Student B: Oh help me, come here please. I've got a headache.

Student C: what's the matter?

Student D: Oh help me, come here please. I've got a tummyache.

Student E: what's the matter?

Student F: Oh help me, come here please. I've got an earache.

Student G: what's the matter?

Student H: Oh help me, come here please. I've got a toothache.

The students were voluntarily in turn acting out the chunk. Even some students wanted to have the second chance of coming up in front of the class practicing the chunk. However, the teacher many times used Bahasa Indonesia when the students seemed confused and did not have an idea about what she was explaining about. Also, it seemed that the teacher's voice was not really loud to be heard to all the students. She sometimes called out some students who did not pay attention to the lesson. There were few boys busy talking themselves. Yet, in general, most students attentively listened and involved in activities set by the teacher. Therefore, the next cycle was needed to encourage the students to be more active and engaged in learning process.

Based on the observation in the second cycle, it could be seen that the students were more enthusiastic and interested in listening to the story. The story was The Very Hungry Caterpillar. The teacher opened the lesson by singing days of the week with the tune "twinkle-twinkle little star". Then the teacher had the students sing along. In introducing the story, the teacher showed a caterpillar realia and use flash cards of days, fruits, and things mentioned in the story. The teacher taped the cards of days of the week on the board and asked the students to reorder them from Monday to Sunday. The students were so enthusiastic to come to the front and arrange the cards. In addition to the cards of the days and fruits, the teacher also elicited numbers and colors since the story would deal with those all materials. When the students had known and had been familiar with the vocabularies, the teacher read the big book. Different from what she did in the first cycle, she read the story loudly. Therefore, the students listened attentively and seriously.

The story was about the very hungry caterpillar which ate one red apple on Monday and was still hungry, ate two green pears and was still hungry and so forth until Sunday. Finally the caterpillar became a beautiful butterfly. After reading the story, the teacher had students repeat the story. Then the teacher read the story again and alternated the students to reorder the story cards on the board accordingly. After the students understood the story, the students then acted out the story. The students enjoyed that activity much and everybody actively participated in turn. 


\subsection{Students' Vocabulary Mastery}

In order to find out whether students improved their vocabulary mastery, an assessment was only administered in this cycle. The assessment was vocabularies on numbers and colors that were related to the story. The following is the result of the assessment.

From the score of the assessment can be found that the highest score is 100 and the lowest is 31 . The mean of the score obtained is 80.4, which belongs to good category.

\subsection{Students' Response on Learning Vocabulary Using TPRS}

In this cycle, a questionnaire was administered to know the students' response on learning English through stories. The items of the questionnaire were written in Bahasa Indonesia with simple language since the respondents were second graders of elementary school. The result of the questionnaire can be seen in the following table:

Table 2. Students' Response on Leraning Vocabulary Using TPRS

\begin{tabular}{llll}
\hline No & Questions & Happy & Not happy \\
1 & Do you feel happy learning English through stories? & $100 \%$ & $0 \%$ \\
2 & Can you act out the story after listening to it? & $75 \%$ & $25 \%$ \\
3 & Do you like the stories? & $87.5 \%$ & $12.5 \%$ \\
\hline
\end{tabular}

The table shows that the students were happy and enjoyed learning English by using TPRS. That was a new experience for them. They were only $75 \%$ students could act out the stories. In addition, there were $87.5 \%$ of students loved stories.

\section{Discussion}

This research investigated the influence of TPRS on the students' vocabulary mastery. TPRS was utilized for period of time, exactly in two cycles. From cycle I and cycle II, it is found that during the class, the teacher maximized the media use, such as realia (a crocodile doll), some flash cards and two big books, the book entitled Crocodile Tear employed in cycle I and the other one is The Hungry Catterpillar which was used in cycle II. She used them to invite students' interest and make the students concentrate to the topic. By showing a realia, she pointed body parts of crocodile without mentioning the Indonesian meaning of them. Some of the conversation between the teacher and the students are transcribed below.

Teacher : Crocodile's tear (Imitating crocodile's sound by pointing something falling down from its' eyes)

Students : Apa itu Ust (Ustadzah)? Eyes?

Teacher : Hik...hik....hik (Demonstrating how a crocodile cried and pointing tear from her eyes)

Students : Air mata Us.

Teacher : Good. 
Then the teacher continued the story while some time she pointed on the crocodile's body to show the meaning of some words she mentioned. Here, the teacher used Grammar Translation Method. She was many times translating words that might have not been understood by the students. It was intentionally done when the students seemed hard to understand particular words, and was unintentionally done because of having been familiar in doing sort of translation. Surprisingly, a previous research of Castro (2010) indicated that both Grammar-Translation and TPRS ${ }^{\mathrm{TM}}$ approaches made an important difference in student retention of vocabulary. The improvements in vocabulary acquisition and retention were $49 \%$ using GrammarTranslation and $45 \%$ using TPRS ${ }^{\text {TM }}$. Preventing the bias finding of the influence of GTM rather than TPRS on the students' vocabulary mastery, it was an important note that the use of GTM would be reduced in cycle 2 .

The teacher also tried to involve the students as part of the story. Here is the example:

Teacher

: Crocodile meets turtle. Crocodile said, "Hi Turtle! Come here please". (She asked the students to show which of the sentence "Come here, please").

Students

: Saya Us...

Saya Us....

Because many students wanted to come forward, she invited one.

From this description we know that the students' response is very good. They were very active and engaged in the class, since the teacher attractively supported their involvement. Furthermore, the teacher positively managed the class and gave motivation to all students. She not only paid attention to those who came in front of the class but also to those who didn't get the chance. She came closer to them and said, "Siapa yang ngambek akan digigit crocodile" while pointing the crocodile doll. This strategy was very effective to make the students happy and had fun again. Unfortunately, it was spoken in Bahasa Indonesia. And she sometimes responded the students' questions in Bahasa Indonesia because she worried that the students would not understand when she used English. Thus, the exposure to English was not maximally done.

The second cycle was conducted since the reflection of the first cycle revealed that the teacher many times used Bahasa Indonesia, and she also did not read the story loudly. To assure that all students were happy and able to master the vocabulary in the context of stories the second cycle was implemented. In this cycle, the students were also enthusiastic joining the class. They were so happy to have another story entitled "The Very Hungry Caterpillar". The teacher had them to play a game by arranging names of the days on the board as the icebreaking. They competed to come up voluntarily. The teacher also provided a game related to fruits and numbers before reading the story.

After joining two cycles of learning vocabulary by using TPRS, the students showed that they improved their vocabulary mastery. The mean of the score obtained is 80.4 and it belongs to good category. It can be said that they mastered the vocabulary 
since it was taught in a contextual learning that enabled them to keep the vocabulary stay longer in their long-term memory. Also, the students experienced fun English learning by playing game, listening, doing exercises, and acting out the stories. It shows that learning English by using TPRS is effective to improve the students' vocabulary mastery. This finding concurs with the result of previous study but it specifically uses the TPRS teaching technique for students with disabilities. Hellony (2012) revealed that that TPRS is an effective teaching method to learn foreign language. The test average scores were slightly higher for students taught with TPRS methods compared to students educated with traditional methods $(81.1 \%$ to $78.9 \%)$.

From the students' response on learning English through TPRS, it can be seen that all students were happy and enjoyed learning English by using TPRS. There were $100 \%$ students stating that learning through TPRS was a new experience for them. It is in line with Read (2003) and Suhartatik (2008) who proposes some of the optimal conditions for helping young learners to learn, among others are: learning is natural, learning is contextualised and part of a real event, learning is interesting and enjoyable. There were only $75 \%$ students who could act out the stories since they really knew and understood the whole stories. Actually, they loved stories; it was shown that there were $87.5 \%$ of students loved stories. Obviously, it shows that learning English through TPRS is an exciting experience for them. This finding seems in line with Decker (2008) that TPRS provides fun learning and gives opportunities for students to actively engage in the class. This TPRS is alsa contribute to encourage the students' creatity which is needed in learning English (Zaker, 2016) as well as to promote their motivation.

\section{Conclusions}

The findings and the discussions show that the use of TPRS are benefited both the students and the teacher. TPRS can improve the students' vocabulary mastery. It is in line with Scott and Lisbeth (1990:30) that children do love stories. Similarly, Wright (1997) and Garvie (1990) argue that stories will be useful either to the students' development in the class or to their language development. Moreover, stories accompanied by action. In this case, it is TPRS. The stories are presented together with the physical activities. Instead of loving stories, kids love story very much. Moreover, they like moving and learning by doing of which are covered by TPR storytelling. This method provides the students to have less stress classroom situation that allows them to be involved in the story by imitating what the teacher says and performing the story then. The improvement also takes place in the teaching and learning process. The teacher makes use of stories better. The teacher has a new teaching practice experience that is utilizing story.

In other words, TPRS is effective to be used in teaching vocabulary for some reasons. This method enables students to memorize and understand the vocabulary in a contextual meaning. It is also a new experience for them learning English through stories. Therefore, they experience a fun learning and perform better in vocabulary achievement. It is in line with the findings obtained Castro (2010) that TPR Storytelling is effective for vocabulary acquisition. 


\section{Suggestions}

Based on the conclusions, there are some suggestions presented. For the teacher, it is expected that the teacher can make use of other stories by considering vocabularies that meet with the syllabus and the students' need. It is necessary to really design the story in order to help the students learn the language based on their level. Yet, designing an appropriate new story might not be easy. Another idea is that compiling the target languages and modifying them to be a story. The story might be contained moral values and messages to be in line with the school curriculum emphasizing on students' character building. The presence of media will also help the students to understand the stories. easily. And, the more the teacher uses stories, the greater opportunity for students to acquire more vocabularies. Moreover, inviting and involving students to persistently participate will give them a feeling of success in learning. Responding to that, the institution needs to fully support and provide sufficient resources such as big book, pictures, or flash cards for betterment of English learning for students. For further researchers who are interested in the same field, this research hopefully could be the reference. The use TPRS to improve skills or other language component might be another idea for the next research.

\section{References}

Arizpe, Evelyn and Styles, Morag. (2003). Children Reading Pictures. London: Routledge Falmer.

Asher. (2001). How to Apply TPR Storytelling for Best Results. http://www.tprworld.com/tpr-storytelling.html (retrieved on March 20, 2015)

Asher. (2006). TPR Storytelling With High School and College Students: Our Personal Experience. tprworld@aol.com (retrieved on March 20, 2015)

Castro, Ruben. (2010). "A Pilot Study Comparing Total Physical Response Storytelling With the Grammar-Translation Teaching Strategy to Determine Their Effectiveness in Vocabulary Acquisition among English as a Second Language Adult Learners" (2010). Master's Theses and Capstone Projects. Paper 111

Davidheiser, J. (2002). Teaching German with TPRS (Total Physical Response Storytelling). Die Unterrichtspraxis/ Teaching German, 35, 25-35

Decker, Beth. (2008). Body language: The Effectiveness of Total Physical Response Storytelling in Secondary Foreign Language Instruction. www.macalester.edu/.../action\%20research\%20-\%20beth.pdf

Cameron, L. (2003). Teaching Languages to Young Learners. Cambridge: University Press

Garvie, E. (1990). Story as Vehicle. Clevedon, Avon: Multilingual Matters.

Holleny, Laura. (2012). The Effectiveness of Total Physical Response Storytelling for Language Learning with Special Education Students. Theses and Dissertations. Paper 197

Jabar, Norina \& Ali, Afiza Mohamad. (2016). Cultural Video Project Assignment (VPA) through the Eyes of Young ESL Learners: A Multi-Modal Vocabulary Learning Approach. Indonesian Journal of EFL and Linguistics, 1(2), 2016 
McKay, Todd. (2004). TPR Storytelling: Especially for Students in Elementary and Middle School. Los Gatos, CA: Sky Oaks Productions, Inc.

Mills, Geoffrey. (2004). Action Research. New Jersey: Merrill Prentice Hill.

Munir, Fathul. (2016). The Effectiveness of Teaching Vocabulary by Using Cartoon Film toward Vocabulary Mastery of EFL Students. Journal of English Language Teaching and Linguistics, 1(1), 2016

Nunan, D. (1991). Language Teaching Methodology: A textbook for teachers. London: Prentice Hall.

Sarani, Abdullah and Shirzaei, Habib. (2016). A Comparative Study of Vocabulary Learning Strategies Employed by Iranian Undergraduate and Postgraduate EFL Learners with a Focus on Motivation. Indonesian Journal of EFL and Linguistics, Vol. 1 (1), 2016

Scott, Wendy A and Lisbeth H. Ytreberg. (1990). Teaching English to Children. London: Longman.

Sinhaneti, Kantatip and Ei Kalayar Kyaw. (2012). A Study of the Role of Rote Learning in Vocabulary Learning Strategies for Burmese Students

Sommer, A. (2011). System Competence : Are elementary school students ask to task to Seal with a biological system? http://www.naturfagsenteret.no/c1515603/binfil/download2.php?tid=1568379 Retrieved 2 Februari 2017

Suhartatik. (2008). Teaching English for Young Learners. Paradigma, Tahun XIII, Nomor 25, Januari-Juni 2008.

Yuvaraj, A. (2009). Age Factor and Its Implication for Teaching English to Young Learners. MJALI, 6 November 2009

Wright, A. (1997). Creating Stories with Children. Oxford: Oxford University

Zaker, Alireza. (2016). Literature and Creativity in an ELT Context. ASIAN TEFL, 1(2), 2016 